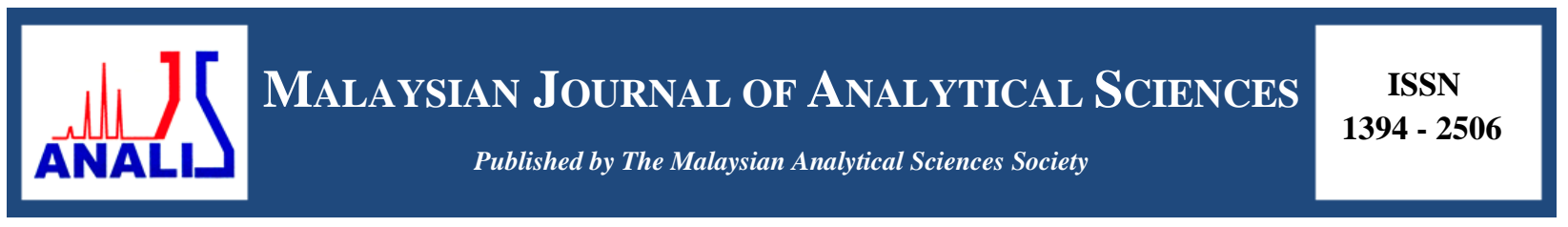

\title{
THE EFFECT OF CTAB AND SDS SURFACTANT ON THE MORPHOLOGY AND PERFORMANCE OF LOW PRESSURE ACTIVE REVERSE OSMOSIS MEMBRANE
}

\author{
(Kesan Surfaktan CTAB dan SDS Terhadap Morfologi dan Prestasi Membran Osmosis Berbalik \\ Aktif Bertekanan Rendah)
}

\author{
Nurul Syuhada Mohd Ali and Abdul Rahman Hassan* \\ Industrial Membrane Technology Lab (IMTL), Department of Industrial Chemical Technology, \\ Faculty of Science and Technology, \\ Islamic Science University of Malaysia, 71800 Nilai, Negeri Sembilan, Malaysia \\ *Corresponding author: abdrahman@usim.edu.my
}

Received: 24 February 2015; Accepted: 27 October 2015

\begin{abstract}
This study reported on the preparation of newly low pressure active reverse osmosis (LPARO) membrane by phase inversion technique. The effect of cetyl trimethylammonium bromide (CTAB) and sodium dodecyl sulphate (SDS) as surfactants on performance and morphological structure were examined. Using brackish water as a sample, the membrane performance was evaluated in terms of pure water permeation (PWP), flux and salt rejection. Experimental data revealed that at $2.0 \mathrm{wt}$. \% of SDS, the LPARO membrane achieved the optimum performance and produced the finest membrane.
\end{abstract}

Keywords: low pressure reverse osmosis, surfactant, morphology, performance, brackish water

\section{Abstrak}

Kajian ini melaporkan mengenai penyediaan membran osmosis songsang aktif bertekanan rendah (LPARO) dengan teknik fasa penyongsangan. Kesan setil trimetilammonium bromida (CTAB) dan natrium dodekil sulfat (SDS) sebagai surfaktan terhadap prestasi dan struktur morfologi telah diselidik. Dengan menggunakan air payau sebagai contoh, prestasi membran telah dinilai dari segi penyerapan air tulen (PWP), penyingkiran fluks dan garam. Data eksperimen menunjukkan bahawa pada $2.0 \mathrm{wt} . \%$ SDS, membran LPARO berjaya mencapai prestasi yang optimum dan menghasilkan membran yang terbaik.

Kata kunci: osmosis songsang bertekanan rendah, surfaktan, morfologi, prestasi, air payau

\section{Introduction}

Asymmetric membranes are prepared by phase inversion via immersion precipitation [1]. In this process, it involves the conversion of a homogeneous polymer solution consisting of two or more components to a two-phase system, the solid polymer rich phase and the liquid polymer poor phase. The solid phase forms the membrane structure while the liquid phase forms the membrane pores [2]. The successive solidification of the phase separated solution leads to a porous, asymmetric structure. The morphology and performance of membranes depend strongly on the thermodynamics as well as kinetics of the phase inversion process [3].

One option for controlling the membrane formation process is introducing an additive in the casting solution. PVP is a well-known additive that can increase the viscosity of the polymer solution. Several studies were done on the 


\section{Nurul Syuhada \& Abdul Rahman: THE EFFECT OF CTAB AND SDS SURFACTANT ON THE MORPHOLOGY AND PERFORMANCE OF LOW PRESSURE ACTIVE REVERSE OSMOSIS MEMBRANE}

effect of PVP as additive on the morphology and performance of membranes. Han and Nam [4] studied the variation of thermodynamic and rheological properties in PSF casting solution by adding PVP. Jung et. al [5] investigated the effect of molecular weight of polymeric additives on formation, permeation properties and hypochlorite treatment of asymmetric polyacrylonitrile (PAN) membranes. The results indicated that the top layer of the membrane and suppression of macrovoid formation strongly depends upon the molecular weight of PVP. Besides that, Fontananova et. al [6] and Curcio et. al [7] reported that PVP was an effective permeation flux promoter, and the thermodynamic effect played a dominant role during the flat-sheet membrane formations of both polyvinylidine fluoride (PVDF) homopolymer and PVDF-HFP copolymer. Also, the preparation, morphology and performance of cellulose acetate (CA)/polyvinylpyrrolidone (PVP) blend asymmetric membranes has been studied by Saljoughi and Mohammadi [8]. It was found out that initial addition of PVP to the cast film solution (from 0 to 3 wt. \%) results in increasing macrovoids formation, meanwhile further addition of PVP (from 3 to $6 \mathrm{wt}$. \%) results in suppression of macrovoids.

Addition of surfactant as one of the materials necessary for membrane making formulation can be one of the effective strategies to produce high performance membrane with high selectivity. The effects of surfactants as additive in the process of membrane fabrication were reported in other studies [9-13]. Sodium dodecyl sulphate (SDS) was added as additive into polysulfone (PSF) casting solution for gas separation and as gelatin media on the formation of polyethersulfone (PES) membranes by Yamasaki et. al [9] and Alsari et. al [10], respectively. The effects of temperature and concentration of cationic surfactant, which is cetyl trimethylammonium bromide (CTAB) in the formation of asymmetric nanofiltration membrane is reported by Mulijani et. al [11]. The result indicated that the formation of membrane pore increases as the addition of CTAB increases. Saedi et. al [12] investigated the effect of three types of surfactant including SDS, CTAB and Triton X-100 on the structure and performance of PES membrane for carbon dioxide separation from methane. The result demonstrated that the addition of surfactants in the casting solution increases the formation of macrovoids and large finger-like pores in the sub-layer of PES membranes. The effect of CTAB and Triton X-100 on the surface morphology and nitrophenols separation using CA nanofiltration membrane was investigated by Ghaemi et. al [13]. Addition of surfactants as additive resulted in membranes with superior pure water flux, permeation and rejection in comparison to CA membrane.

\section{Chemicals and raw materials}

\section{Materials and Methods}

Polysulfone (PSF (Udel-P1700) (Solvay) was used as polymer, while N-methyl-2-pyrrolidone (NMP) (Merck) was used as non-solvent for membrane preparation. Polyvinylpyrrolidone, (PVP, K29-32) (Acros Organics) was used as additive. Cetyl trimethylammonium bromide (CTAB) (EMD Chemicals) and Sodium Dodecyl Sulphate (SDS) (Fisher Scientific UK) were used as cationic and anionic surfactant for addition in the casting solution. Ethanol and n-hexane (Merck) were used as the coagulation bath. Sodium chloride, $\mathrm{NaCl}$ (Merck) was used for the salt rejection test.

\section{Membrane preparation}

Homogeneous dope solution of the PSF dissolved in NMP was prepared using PVP as additive, and different surfactants which are CTAB as cationic surfactant and SDS as anionic surfactant by stirring for 8 hours at room temperature. The stirring process was fixed at $300 \mathrm{rpm}$. The solution was poured and cast on glass plate using casting knife with thickness of $150 \mu \mathrm{m}$. Then, the membrane was moved into water for immersion precipitation. The immersion precipitation was carried out at room temperature. In order to ensure complete phase separation, the membrane was immersed in water for 24 hours. Then, the membrane was immersed in ethanol for 24 hours and $\mathrm{n}$ hexane for 3 hours to ensure all the solvents is completely removed. As the final stage, membrane was dried for 24 hours.

\section{Membranes morphological characteristics}

The cross-section of the prepared low pressure reverse osmosis (LPARO) membranes was investigated using scanning electron microscopy. Samples of the membranes were fractured cryogenically in liquid nitrogen and mounted on the sample stubs with double-surface tape. After the samples were sputtered with gold by an automatic gold coater (JFC 1600), they were scanned by employing a JEOL JSM 6360LA Scanning Electron Microscopy (Tokyo, Japan) under magnification of $500 \mathrm{x}$ to $5000 \mathrm{x}$ with potentials $15 \mathrm{kV}$. 


\section{Reverse osmosis performance evaluation}

Reverse osmosis performance in terms of pure water permeation (PWP) and salt rejection for the LPARO membranes were tested using lab-scale cross flow filtration apparatus with circular filtration cell having an effective area of $1.38 \times 10^{-3} \mathrm{~m}^{2}$. To begin with, the circular membrane coupons loaded in the filtration cells were pressured at 5 bar with deionized water for at least 30 minutes for compaction. Desalination tests were then carried out at operating pressure of $5 \mathrm{bar}$ with aqueous solution containing $2000 \mathrm{ppm}$ of $\mathrm{NaCl}$ represent brackish water. The PWP was determined by measuring the permeate volume collected over a certain period in terms of liter per square meter per hour $\left(\mathrm{L} / \mathrm{m}^{2} \mathrm{~h}\right)$ and calculated through the following equation 1 :

$$
J_{\mathrm{w}}=\frac{\mathrm{Q}}{\mathrm{A} \times \Delta \mathrm{t}}
$$

where $\mathrm{J}_{\mathrm{w}}$ is the volumetric PWP, A is the effective area of the membrane for permeation, and Q is the volume of permeation over a time interval $(\Delta \mathrm{t})$. The salt rejection was evaluated using the following equation 2 :

$$
\mathrm{R}=\left(1-\frac{\mathrm{C}_{\mathrm{p}}}{\mathrm{C}_{\mathrm{f}}}\right) \times 100
$$

in which $C_{p}$ and $C_{f}$ are the salt concentrations in permeate and feed, respectively. The salt concentration was determined by measuring the electrical conductivity of the salt solution using a conductivity meter (CON 700, Eutech Instruments).

\section{Results and Discussion}

Effect of CTAB as cationic surfactant on the performance of PSF membrane

Figure 1 shows that the presence of $\mathrm{CTAB}$ in the casting solution increases the PWP values with the maximum value of $1 \mathrm{wt}$. \% CTAB. Increasing $\mathrm{CTAB}$ concentration more than $1 \mathrm{wt}$ \% resulted in decreasing the PWP. This might due to the high viscosity of casting solution that prevents the penetration of non-solvent and weaken the macrovoids formation, hence lead to low permeability of membrane.



Figure 1. Effect of CTAB concentration on pure water permeation

The effect of $\mathrm{CTAB}$ concentration on brackish water flux and salt rejection of membrane prepared from $\mathrm{PSF} / \mathrm{NMP} / \mathrm{PVP} / \mathrm{CTAB}$ system is shown in Figure 2. The brackish water flux increases as CTAB surfactant introduced in the casting solution, reaches the maximum at 1 wt. \% concentration of CTAB which is $32.48 \mathrm{~L} / \mathrm{m}^{2} \mathrm{~h}$. The salt rejection improves from $77.8 \%$ (without $\mathrm{CTAB}$ ) to $81.1 \%$ in the presence of $2 \mathrm{wt}$ \% of CTAB in the 
casting solution. As the $\mathrm{CTAB}$ concentration increased more than $2 \mathrm{wt} \%$, the salt rejection gradually decreased. The cross-sectional morphology of the prepared membrane with CTAB (Figure 5b) justify the high PWP and brackish water permeation in the presence of $\mathrm{CTAB}$ due to the formation of large finger-like pore in the sub-layer of membranes.

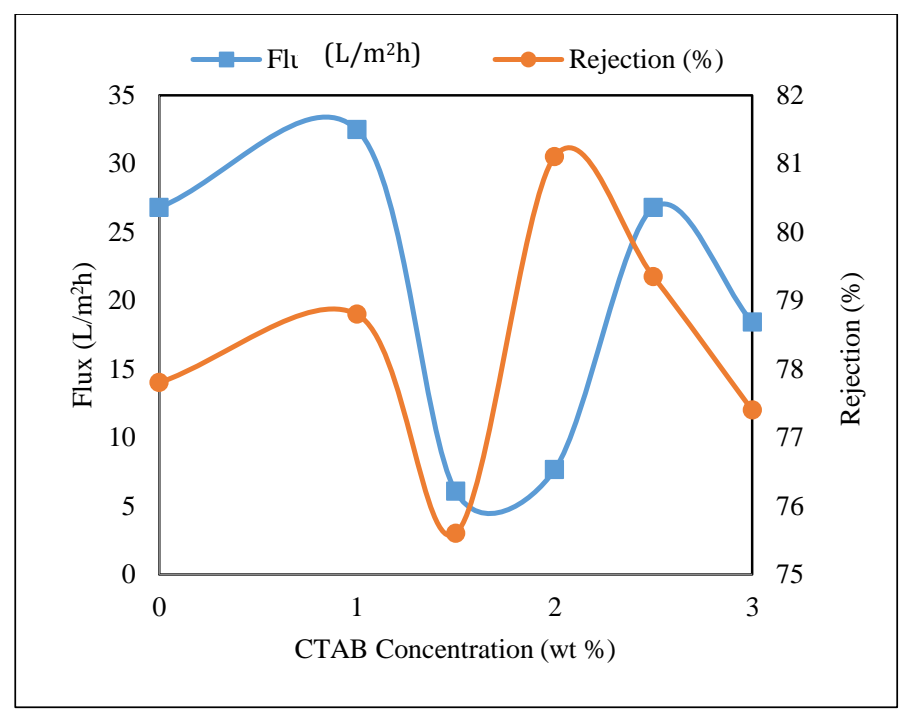

Figure 2. Effect of CTAB on brackish water flux and salt rejection

\section{Effect of SDS as anionic surfactant on the performance of PSF membrane}

To investigate the effect of anionic surfactant as additive in the casting solution, sodium dodecyl sulphate (SDS) was selected as strong anionic surfactant. Figure 3 show the effect of SDS concentration on PWP for the prepared membrane. The PWP increases gradually by increasing the SDS concentration in the casting solution, and reaches the maximum value for the concentration of $2.5 \mathrm{wt}$ \% SDS, then decreases afterwards. This corresponds with the finding of Rahimpour et al. [3].

The effect of SDS on brackish water flux and salt rejection are shown in Figure 4. The obtained results demonstrated that the addition of SDS in the casting solution enhance the brackish water flux and salt rejection. On the other hand, as the concentration of SDS increases more than $2.5 \mathrm{wt} . \%$, the brackish water flux and salt rejection decreases.

Most surfactants have a long hydrophobic alkali and a hydrophilic ionic group (polar group) in their structure. Rahimpour et al. [3] reported when the surfactant enters in aqueous media the ionic head tends to water while the non-polar tail tends to absorb on solid surface, air or organic phase. The alkali chain can join to polymer matrix when it comes near to hydro-carbonic structure of polymer but the hydrophilic but the hydrophilic and polar portion leave freely. The accumulation of polar groups in polymer structure results in repulsion between polymer chains and consequently increases the porosity of membrane by forming an open structure. When concentration of the surfactant increase, the non-polar tail of surfactant molecules settle beside one another and form micelles with polar groups in outer surface and non-polar groups inside the micelles in addition to the polymer surfactant complex. These free micelles deteriorate the membrane structure and decrease the membrane performance [11]. 


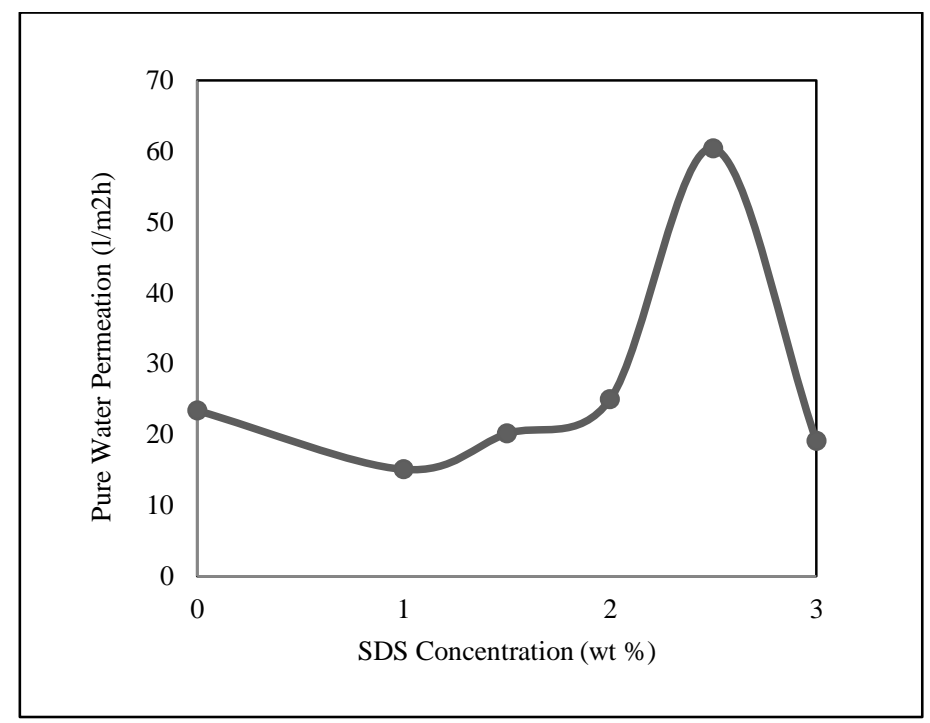

Figure 3. Effect of SDS concentration on pure water permeation

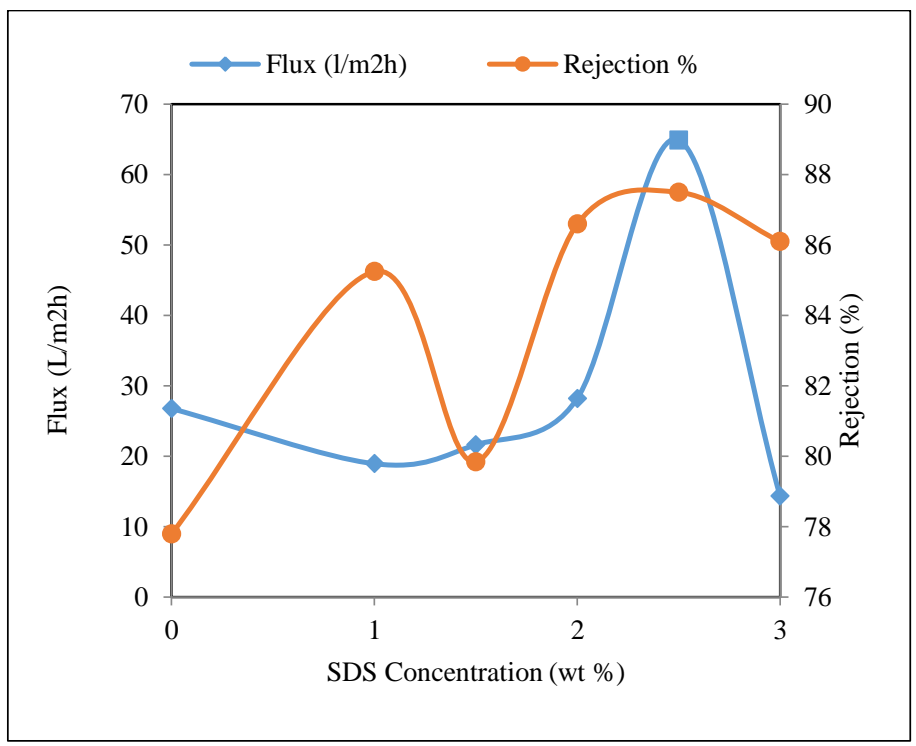

Figure 4. Effect of SDS on brackish water flux and salt rejection

\section{Effect of surfactants on the morphology of the PSF membrane}

The scanning electron microscopy (SEM) images were taken to determine the effect of CTAB and SDS as surfactants on the surface morphology of the LPARO membranes. SEM photograph of cross section of membranes, prepared from PSF membrane without surfactant, with CTAB and SDS as shown in Figure 5(a), 5(b) and 5(c), respectively. Asymmetric structure of the membranes consists of a dense top layer, a porous sub-layer that is occupied by closed cell within polymer matrix, and finger-like pores. The SEM images indicate that the addition of $\mathrm{CTAB}$ in the casting solution lead to formation of large finger-like pores in sub-layer of membranes. There is evident correlation between the miscibility of surfactant in the coagulant and the formation process of various pores. 


\section{Nurul Syuhada \& Abdul Rahman: THE EFFECT OF CTAB AND SDS SURFACTANT ON THE MORPHOLOGY AND PERFORMANCE OF LOW PRESSURE ACTIVE REVERSE OSMOSIS MEMBRANE}

Addition of an appropriate surfactants leads to induction or suppression of the macrovoids and finger-like pores in the sub-layer [3]. Although there is low miscibility between CTAB and NMP, CTAB is classified as hydrophilic surfactant that has high miscibility in water. If the added surfactant to the casting solution has high miscibility with the coagulant, it resulting in formation of finger-like pores and macrovoids via decreasing the surface tension and subsequently decrease in the demixing time [12].



(a)

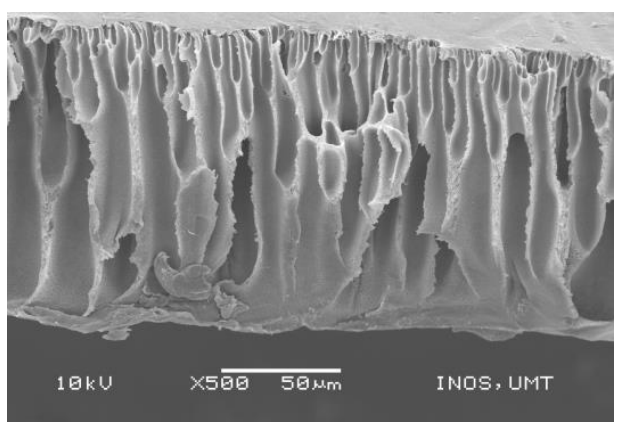

(b)

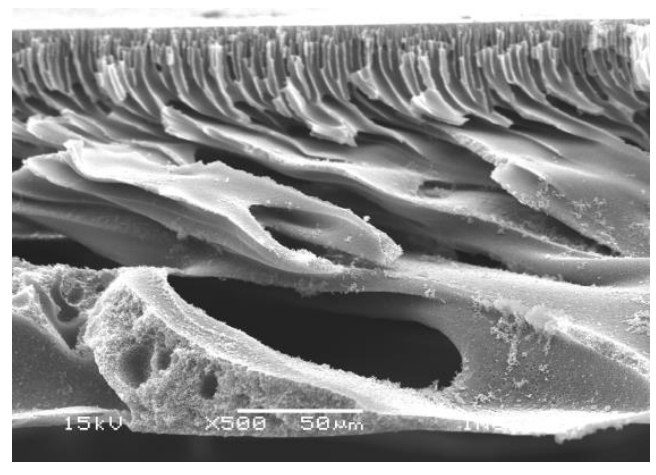

(c)

Figure 5. SEM cross-sectional images of prepared PSF membranes (a) without surfactant, (b) with CTAB and (c) with SDS

Meanwhile, SDS as hydrophilic surfactant can affect membrane morphology and porosity of sub layer in three manners which are (i) enhancement in macrovoid formation and increasing the membrane porosity by increasing solvent-nonsolvent mixing affinity and increasing demixing rate via distribution of SDS molecules as free molecules in NMP and formation of free micelles, (ii) enhancement in membrane free volume and membrane porosity and macrovoid formation via formation of polymer-surfactant complexes, (iii) decreasing sub layer porosity by decreasing demixing rate via increasing casting solution viscosity [12]. The SEM images indicated that the addition of small amount of SDS in the casting solution enhanced macrovoids formation. The high porosity of sub-layer of membranes prepared with SDS can be responsible for high performance of membranes.

\section{Conclusion}

This study has demonstrated that the addition of surfactants in the casting solution increases the formation of macrovoids and large finger-like pores in the sub-layer of LPARO membranes. This enhance the pure water permeation, brackish water flux with slight decrease in salt rejection. Surfactant concentration plays an important 
role in the membrane morphology and performance. The obtained result revealed that at $2.0 \mathrm{wt} . \%$ of SDS, the LPARO membrane achieved the optimum performance and produced the finest membrane.

\section{Acknowledgement}

The authors would like to thank to Ministry of Education (MOE), Malaysia through Exploratory Research Grant Scheme (USIM/ERGS-FST-33-50113) for their financial assistance and support.

\section{References}

1. Strathmann. H. and Koch. K. (1977). The formation mechanism of phase-inversion membranes. Desalination, 21: $241-255$.

2. Yuxin, M., Fengmei, S., Jun, M., Miaonan. W., Jun, Z. and Congjie, G. (2011). Effect of PEG addiive on the morphology and performance of polysulfone ultrafiltration membranes. Desalination, 272: $51-58$.

3. Rahimpour, A., Madaeni, S. S. and Mansourpanah, Y. (2007). The effect of anionic, non-ionic and cationic surfactants on morphology and performance of polyethersulfone ultrafiltration membranes for milk concentration. Journal of Membrane Science, 296: 110 - 121.

4. Han, M. J. and Nam. S. T. (2002). Thermodynamic and rheological variation in polysulfone solution by PVP and its effect in the preparation of phase inversion membrane. Journal of Membrane Science, 202: 55 - 61 .

5. Jung, B. Yoon, J. K., Kim, B. and Rhee, H. (2004). Effect of molecular weight of polymeric additives on formation, permeation properties and hypochlorite treatment of asymmetric PAN membranes. Journal of Membrane Science, 243: 45 - 57.

6. Fontananova, E., Jansen, J. C., Cristiano, A., Curcio, E. and Drioli, E. (2006). Effect of additives in the casting solution on the formation of PVDF membranes. Desalination, 192: 190 - 197.

7. Curcio, E., Fontananova, E., Di Profio, G. and Drioli, E. (2006). Influence of the structural properties of poly (vinylidene fluoride) membranes on the heterogeneous nucleation rate of protein crystals. The Journal of Physical Chemistry B, 110(25): $12438-12445$.

8. Saljoughi, E. and Mohammadi, T. (2009). Cellulose acetate (CA) / polyvinylpyrrolidone (PVP) blend asymmetric membranes: Preparation, morphology and performance. Desalination. 249: 850 - 854.

9. Yamasaki, A., Tyagi, R. K., Fouda, A. E., Jonnason, K. and Matsuura, T. (2000). Effect of SDS surfactant as an additive on the formation of asymmetric polysulfone membranes for gas separation in: Pinnau, I., Freeman, B.D. (Eds.), Membrane Formation and Modification, Chapter 6.

10. Alsari, A. M., Khulbe, K. C. and Matsuura, T. (2001). The effect of sodium dodecyl sulfate solutions as gelation media on the formation of PES membranes. Journal of Membrane Science, 188(2): 279 - 293.

11. Mulijani, S., Budianto, E. and Hikam, M. (2010). Formation and Characterization of Asymetric Nanofiltration Membrane: Effect of Temperature and Surfactant as a Template. ASEAN Journal on Science \& Technology For Development, 27: $21-29$.

12. Saedi, S., Madaeni, S. S., Shamsabadi, A. A. and Mottaghi, F. (2012). The effect of surfactants on the structure and performance of PES membrane for separation of carbon dioxide from methane. Separation and Purification Technology, 99: 104 - 119.

13. Ghaemi, N., Madaeni, S. S., Alizadeh, A., Daraei, P., Zinatizadeh, A. A. and Rahimpour, F. (2012). Separation of nitrophenols using cellulose acetate nanofiltration membrane: Influence of surfactant additives. Separation and Purification Technology, 85: 147 - 156. 